\title{
The Banco Central do Brasil's institutional framework after ten years
}

\section{EMMANUEL CARRÉ*}

The Banco Central do Brazil (BACEN) adopted inflation targeting in 1999. This monetary policy regime originates in institutional design which remains crucial today for the expectations management, and is in permanent evolution. After 10 years, the BACEN institutional framework is assessed, asking if there is still room for improvement. Various institutional procedures are analysed, and lessons are drawn from the international experience of a panel of sixteen countries. Some proposals for the BACEN institutional framework are made.

Keywords: inflation targeting; institutional design; transparency; interest rate forecasts.

JEL Classification: C53; D81; E58.

\section{INTRODUCTION}

The creation of the monetary policy regime of “inflation targeting”, in 1989 in New Zealand, was a pragmatic choice ${ }^{1}$. It was the new solution to the traditional search for an expectations anchorage, invented with quasi no specific macromodelling and in opposition with Neo-Classicals and Monetarists recommendation of a policy rule ${ }^{2}$. Nevertheless, its inception was influenced by the academic literature, the institutional design approach in particular' ${ }^{3}$, i.e. 'define the optimal frame-

\footnotetext{
* University Paris XIII. E-mail: carre.emnl@gmail.com. I thank the referees for helpful comments. Submitted: 14/7/2009; Approved: 17/9/2010.

${ }^{1}$ It was far from being a perfect derivation of academic theory (Sherwin, 1999, p. 72). I thank a referee for recommending more precision on this point.

${ }^{2}$ See Reddell (1999, p. 71), Singleton et al. (2006).

${ }^{3}$ The time inconsistency literature had a significant influence, while the central bank independence lit-
} 
work within which judgment will be exercised' (Faust and Henderson, 2004, p. 119). Originally, and still nowadays, it relies on institutional structures with accountability, transparency and communication procedures. Hence, this monetary policy strategy is defined as a policy framework and a communication strategy, stressing the will to manage expectations to reinforce policy effectiveness.

It is today the dominating regime, adopted worldwide by 28 countries in 2008 , and promoted by the International Monetary Fund. It now has its own model embedded in the New Neo-Classical Synthesis (NNS), a mixture of New Classical and New Keynesian (NK) elements. Largely inspired from the Taylor (1979) curve insisting on the inflation-output volatility trade-off, the textbook presentation of this inflation targeting 'science' is based on four equations":

$$
\begin{aligned}
& L=E_{t} \sum_{h=0}^{\infty} \delta^{h}\left[\left(\pi_{i+h}-\bar{\pi}\right)^{2}+\lambda\left(y_{t+h}-y_{t+h}^{*}\right)^{2}+v\left(i_{t}-i_{t-1}\right)^{2}\right] \\
& \pi_{t}=\beta E_{t} \pi_{t+1}+k\left(y_{t}-y_{t}^{*}\right)+\varepsilon \\
& y_{t}=\alpha E_{t} y_{t+1}-\sigma\left(i_{t}-E_{t} \pi_{t+1}\right) \\
& i_{t}=\gamma\left(\alpha\left(\pi_{t+h}-\bar{\pi}\right)+b\left(y_{t+h}-y_{t+h}^{*}\right)\right)+(1-\gamma) i_{t-1}
\end{aligned}
$$

Equation (1) is an intertemporal loss function with three goals: inflation $\pi$ (the inflation target $\bar{\pi}$ ), output $y$ (potential output $y^{*}$ ), and the interest rate $i$ (instrument smoothing). It is called inflation targeting because of the higher weight put on inflation than on output and gradualism $(\lambda, v)$. Due to transmission lags, the central bank is forward-looking, focused on an optimal targeting horizon $h$. Under this "inflation forecast targeting", it reacts to forecasts forming the intermediate target. Equation (2) is a New Keynesian Phillips Curve (NKPC), a theory of inflation driven by forward-looking expectations and stressing an inflation/output trade-off; $\varepsilon$ is an exogenous cost push shock particularly relevant for Brazil ${ }^{5}$. Equation (3) is an IS curve describing monetary policy transmission channels. Equation (4) is a Taylor rule with smoothing.

Despite this macro-modelling, institutional design remains central to inflation

erature had a smaller influence (Sherwin, 1999; Singleton et al., 2006). Inflation targeting was also embedded in a larger reform program founded upon the New Microeconomics with the principalagent and incentives theory, and on democratic principles such as accountability (Sherwin, 1999, p. 75; Reddell, 1999, p. 71). All these approaches had institutional design as a central matter, the time inconsistency literature in particular (Barro and Gordon, 1983, p. 607).

${ }^{4}$ The BACEN's core model has the same form (Bogdanski et al., 2000). Our article focuses on the institutional aspect of inflation targeting. See Svensson (1997) and Clarida et al. (1999) for details of its macro-modelling.

${ }^{5}$ Kanczuk (2004), Arestis et al. (2009, p. 23), Serrano (2010, p. 70). 
targeting, being the way the expectations management implied by the equations is implemented. That is why in this article attention is concentrated on the institutional design dimension of inflation targeting, with a focus on the Brazil case. The BACEN also adopted inflation targeting in June 1999 for practical reasons related to the need for a nominal anchor: it was an emergency solution to limit inflationary pressures following the abortion of the exchange rate targeting ${ }^{6}$. After 10 years, its monetary policy committee's (Copom) institutional design is assessed, asking if there is still room for improvement. Various institutional procedures are inspected: the most frequently discussed as well as the more controversial ones. Lessons are drawn from the international experience of a panel of inflation targeters from industrial countries and emerging market economies, selected for their institutional design relevance, available information and to take Brazil's specificity into account. To enrich the comparison, non inflation targeters from the G3 (Euro area, Japan, USA) are included. Beyond the comparison, some proposals for the Brazilian institutional framework are made.

As a preliminary to the Brazil case study, the institutional design approach is presented: its theoretical background and the literature related to the article (first section). Then the BACEN's assessment begins with the more general aspects of the institutional framework: governance (second section), accountability (third section) and the Monetary Policy Committee (MPC) design (fourth section). Transparency issues are inspected in fifth section, with a particular focus on the two most debated questions: the choice of the interest rate assumption underlying the inflation forecasts and the benefits of publishing the resulting interest rate forecasts. Finally, communication procedures are studied. Table 1 (in annex) synthesising the analysis is structured the same way and columns in brackets refer to this table.

\section{INFLATION TARGETING: INSTITUTIONAL DESIGN IN THEORY AND PRACTICE}

First, the theoretical foundations of the article are exposed: the institutional design approach to inflation targeting. Then is briefly reviewed the literature carrying out, like this article, an international comparison of the operational aspects of inflation targeting institutional design.

The institutional theory of inflation targeting. The institutional design literature $^{7}$ constitutes, as stressed by central bankers ${ }^{8}$, one of the main theoretical background of inflation targeting. The latter was primitively conceptualized in New Zealand in 1989 as an institutional arrangement within the contractual approach

\footnotetext{
${ }^{6}$ Cerisola and Gelos (2009, p. 1217).

${ }^{7}$ Walsh (2000), Siklos (2002).

${ }^{8}$ King (2004).
} 
and strong accountability of the Policy Targets Agreements 9 . More generally, institutional procedures of transparency and communication are inflation targeting pillars (Freedman and Laxton, 2009). Next, at the beginning of the 1990s, an institutional design theory came at the first front of the literature ${ }^{10}$, giving more formal foundations to the inflation targeting (Persson and Tabellini, 1993; Walsh, 1995; Hutchison and Walsh, 1998).

Institutional design is central to the inflation targeting credibility construction by reducing the inflation bias via procedures lowering information asymmetry (transparency, communication); but also via an institutional commitment to price stability (instrument independence) and the design of the monetary policy committee or its members' appointment procedures (Waller, 1992). Incentive contracts with penalties and rewards (accountability, Open letter) embedded in institutional arrangements can also limit time inconsistency. Moreover, there are institutional preconditions for inflation targeting in emerging market economies, central bank independence in particular (Masson et al., 1997; Batini et al., 2005; Freedman and Ötker-Robe, 2010).

The institutional design is also aimed at ensuring the nominal anchor credibility, measured by inflation expectations alignment on $\bar{\pi}$. It frames and coordinates inflation expectations and preferences, ensuring a lock-in effect stabilising the whole economy, so improving macroeconomic performance and social welfare. Indeed, the simple inflation targeting model (eq. 1-4) stipulates that expectations determine macroeconomic variables, inflation in particular (NKPC). This model also claims that expectations are the main transmission channel of monetary poli$\mathrm{cy}$, as stressed by the "expectation management" strategy at the centre of inflation targeting (Woodford, 2003, p. 15). Thus, the institutional design also enhances monetary policy efficiency.

Yet, credibility is not necessary enough to deal with model uncertainty and unforeseen contingencies: inflation targeting faces an inflation/output trade-off in case of severe $\varepsilon$, like in Brazil with imported inflation (Fischer, 1995, p. 204). This regime is too strict in this environment, producing a credibility/flexibility dilemma. The latter is alleviated by the institutional design via flexibility procedures such as escape clauses (Lohmann, 1992, p. 273). This more flexible inflation targeting better suits to emerging market economies specificities.

Finally, the institutional design is a democratic device reducing the democratic deficit that could emerge from central bank independence (Goodhart, 2003, p. 93). Indeed, accountability procedures organize the relation between the central

\footnotetext{
${ }^{9}$ Central bankers claim that originally inflation targeting in New Zealand was not relying upon the Monetarist and New Classical doctrine of the rule as the solution to time inconsistency (Sherwin, 2000, p. 29). They also assert that the central bank independence literature had only a minor influence (Sherwin, 1999, p. 72). On the contrary, the New Microeconomics recommendation of an institutional commitment was very influential. The institutional design was also congruent with the Westminster democratic system (Nicholl and Archer, 1992, p. 316).

${ }^{10}$ See Goodhart (1995, p. 217) who actively participated to the creation of inflation targeting in New Zealand.
} 
bank and elected representatives of the society. More generally, they strengthen inflation targeting democratic legitimacy.

Related literature. The literature studying inflation targeting institutional procedures in practice, like this article, is well developed. Tuladhar (2005) studies governance structures, Petursson (2004) and Heenan et al. (2006) the institutional design in general. Like this article, several authors analyse the BACEN in particular, but generally limit their analysis to the $\bar{\pi}$ design: level, tolerance interval, optimal time horizon, headline or core inflation index and escape clause ${ }^{11}$. Only a few articles perform, like this article, a systematic comparison of Brazil to the international standards of inflation targeting institutional design ${ }^{12}$; and they also generally restrict their comparison to $\bar{\pi}$ design aspects, not examining the transparency, communication or MPC design.

This article contributes to this literature by updating international comparisons with the most recent development in institutional design: the MPC design ${ }^{13}$, but also the forecasting aspects of transparency with the elaboration and publication of interest rate forecasts ${ }^{14}$. It also examines the communication aspects of institutional design that are usually not considered ${ }^{15}$. Finally, it is one of the first large review of this literature for the Brazilian case.

After these preliminary analyses, we turn to the core of the article: the appraisal of the BACEN design on an international basis. Four main components of its institutional design are successively assessed: governance, accountability, monetary policy committee, transparency and communication ${ }^{16}$.

\section{GOVERNANCE}

This notion, developed by inflation targeters, has replaced the independence doctrine (Crowe and Meade, 2007). The latter was related to the credibility construction via the inflation bias reduction, while governance aims at building central bank's legitimacy via independence limited to instruments (no goal independence)

\footnotetext{
${ }^{11}$ Bogdanski et al. (2000), Ferreira and Petrassi (2002), Giambiagi and Carvalho (2002), Minella et al. (2002), Rocha and Oreiro (2008), Arestis et al. (2009), Montes (2010).

${ }^{12}$ Giambiagi et al. (2006), Rocha and Curado (2009).

${ }^{13}$ Some exceptions are Giambiagi et al. (2006) and Strachman (2009) but they don't make reference to the CPM literature and do not make international comparison of MPC design.

${ }^{14}$ Mendonça and Inhudes (2010) analyse the Bacen transparency, but do not evoke the case for interest rate forecast publication. Feitosa and Tabak (2008) study interest rate survey-based forecasts for Brazil but not the implications for institutional design (publication).

${ }^{15}$ Costa Filho and Rocha (2009) examines the BACEN's communication, but not in the institutional design perspective.

${ }^{16}$ These key components of inflation targeting institutional design have been selected after a review of the literature mentioned before, IMF working papers in particular (Tuladhar, 2005; Heenan et al., 2006; Freedman and Laxton, 2009).
} 
to reduce the democratic deficit. What matters is not isolation, but the relation between the central bank and the government, as shown in the New Zealand's, United Kingdom or Brazil's contractual approach. The different components of governance are examined.

The mandate. By definition, inflation (price stability) is inflation targeting prominent goal. Yet, legal mandates indicate secondary goals, usually related to output. But its role is unclear, the mandate being either hierarchical (inflation first, then output) or lexicographic (output is considered if it does not impair price stability). Moreover, the mandate, often voted before, does not necessarily fit to inflation targeting and is thus reinterpreted by central banks, usually in line with the NNS: inflation stability is the best way to ensure growth (Meirelles, 2007, p. 1) ${ }^{17}$. Is this a new version of the classical long-run neutrality, or is price stability only a mean to reach growth? Following Tinbergen, the Copom states that having one instrument, the interest rate, it has only one goal, price stability (Meirelles, 2008, p. 1).

This raises some problems. First, during the current financial crisis central banks have used another instrument (the quantity of money, not its price). Even with the sole interest rate, output can be targeted. Secondly, theory clouds this debate on the mandate since equation (1) does not contain one but three goals, and the underlying Taylor curve suggests a dual mandate. In theory the Copom maximises social welfare, so has no reason to have a unique mandate on price stability. In the real world, inflation targeters have become more flexible, evolving towards the Fed's dual mandate ${ }^{18}$. Australia for example has a dual mandate, and the recent amendment of the New Zealand's Policy Targets Agreement looks like a dual mandate (Table 1, column 1). Copom's response to the 2002 troubles also shows some weight put on $y$, because e generates a large inflation-output trade-off. It should avoid Mishkin's 'dirty little secret of output': talking only about inflation while taking output into account threatens transparency.

Target setting. According to the credibility literature, the central bank should set $\bar{\pi}$ to avoid government time-inconsistency. Inflation targeters refute this inflation bias hypothesis, insisting instead on democratic legitimacy and accountability like in the New Zealand's contractual approach. Monetary policy derives from society and its elected representatives, who are the principal of the contract, so that in theory they are responsible for setting $\bar{\pi}$, what makes the agent (MPC) accountable for respecting the contract, like in the United Kingdom or Brazil (column 2). For coordination and balance of powers reasons, $\bar{\pi}$ can be decided jointly: this is $d e$ facto the case, and could be de jure to promote transparency ${ }^{19}$. The inflation target can also be defined in the constitution or changed every 6 years like in Canada, instead of 2 years in Brazil. Yet, in light of Copom's difficulties to respect $\bar{\pi}$ and its

\footnotetext{
${ }^{17}$ In theory, this "divine coincidence" of the two goals of inflation and output only occurs in special conditions (e.g. the absence of $\varepsilon$ ), not fulfilled in the case of Brazil.

${ }^{18}$ Greenspan (2004).

${ }^{19}$ The governor of the BACEN is a member of the Conselbo Monetario Nacional (CMN) deciding $\bar{\pi}$.
} 
need for flexibility, such rigid arrangements are neither credible nor necessary recommendable.

Escape clause. Rogoff (1985) establishes that inflation targeting works for demand shocks, not for $\varepsilon$ where the inflation and output goals do not coincide, generating an inflation-output trade-off (eq. 2). Flexibility of the $\bar{\pi}$ tolerance interval could not be enough to deal with this dilemma, calling for an escape clause giving even more flexibility ${ }^{20}$. It deals with unforeseen contingencies that, by definition, could not be specified in the incomplete $\bar{\pi}$ contract. This is particularly the case in emerging market economies (column 3) facing large exogenous e coming from the exchange rate that the MPC is unable to deal with, like Brazil in 2002. During this period, the Copom innovated with a 'target adjustment procedure' considered as a "best practice" to solve imported inflation (Mishkin, 2004). If this innovation resembles an escape clause, the Copom pretends not to have one: a source of opacity. As numerous targeters (column 3), the Copom could benefit from the institutionalisation of such procedure giving more flexibility and reducing the current imperfectly transparent situation; the credibility cost would be limited since after ten years the Copom's reputation is well established.

\section{ACCOUNTABILITY}

The democratic deficit generated by monetary policy delegation to an independent MPC can be reduced by efficient accountability procedures: society, through its elected representatives, checks that the MPC follows its mandate, i.e. shares the same loss function (eq. 1). The main accountability procedures are analysed.

Override procedure. Usually only temporary, it mainly acts as an incentive for the MPC to respect society's preferences. For instance, to avoid being overridden, the MPC can abandon the $\bar{\pi}$ commitment, increasing the flexibility to respond to e (Lohmann, 1992, p. 273). The high political cost of this procedure persuades the government to use it only when it is justified (column 4), so that Brazil could benefit from this procedure.

In case of large deviation from $\bar{\pi}$, the open letter forces the MPC to explain, in a letter to the government, the reason of the deviation, the strategy to return to $\bar{\pi}$ (column 5). This "public humiliation" is supposed to inflict large losses to the MPC which main asset is public prestige, and thus to be an efficient incentive mechanism dissuading to break the $\bar{\pi}$ commitment. Copom's 'target adjustment procedure' is a more formal quantitative justification than the Bank of England's (BoE) qualitative explanation ${ }^{21}$. The latter's experience reveals it is as much a constraint as a source of flexibility. It reminds the government is responsible for the

\footnotetext{
${ }^{20}$ See Mendonça (2002, p. 47), Ferreira and Petrassi (2002, p. 19). For the opposite view, see Minella et al. (2002, p. 39).

${ }^{21}$ The BoE sent five open letters (2007, three in 2008 and one in 2009) and the Copom three (2002, 2003, 2004).
} 
$\bar{\pi}$ decision, and can answer to the letter by disagreeing or by changing $\bar{\pi}$. In Brazil, while deciding $\bar{\pi}$ is a CMN's prerogative, it can be adjusted by the Copom. This situation can be considered as a democratic deficit, calling for change.

The monetary policy independent review asked by the government has become standard (column 6). Realised by leading economists making recommendations that central banks often integrate, it is a source of improvements. To our knowledge it does not exist in Brazil while it could be easily ordered by the government.

\section{MPC DESIGN}

This recent area of research raised with central bank independence and inflation targeting, putting the emphasis on the decision making process transparency in particular. It is now a research domain per se with a typology and a sketch of optimal MPC design. The BoE is considered as the model but is now challenged by the Riksbank. Three principal characteristics of the MPC design are dissected.

An MPC typology of autocratically-, individualistic- and truly- collegial committees is proposed by Blinder (2004). With a charismatic president as a leader, Greenspan's Fed or Mboweni's South African Reserve Bank embody the autocratic type. BoE's individualistic type is given as the best practice and rests upon an individualistic accountability requiring individual votes' publication. The truly collegial form is typically the European Central Bank (ECB) deciding by consensus and having a collective accountability, the decision being a collegial process. The New Zealand or Israel single decision-maker case is not that different from a MPC because the governor benefits from advisors. The Copom, inspired by the BoE, is of the individualistic type, but not in a perfectly consistent manner since individual accountability appears weak with no individual votes' publication.

The MPC size is a complex question depending on many factors; but the Copom 8 members is judged optimal, equal to the theoretical size ${ }^{22}$.

The MPC composition. According to the 'science', based on the BoE, the MPC superiority over a single decision-maker comes from its diversity of views, i.e. its composition institutionalised by the internal/external nomination process (column 8). Diversity acts as a robustness strategy against model uncertainty (McCallum, 1988). Although the Copom has no formal outsiders/insiders composition, it is almost de facto the case and the organisation de jure would institutionalise and reinforces the diversity gains ${ }^{23}$.

The transparency aspects of Copom's institutional design are now analysed.

\footnotetext{
${ }^{22}$ Ehrart and Vasquez-Paz (2007).

${ }^{23}$ Also suggested by Giambiagi et al. (2006, p. 469). Strachman $(2009$, p. 18) proposes to increase the Copom's size to include external members representing different sectors of society, like at the Reserve Bank of Australia. Cacophony is diversity main risk, but it is a very limited one.
} 


\section{TRANSPARENCY}

This is the institutional design dimension the more studied in the literature, calling for long developments. It is endogenous to the policy regime and the MPC design, meaning that practices can vary with no "one best way". This generates debates on minutes, forecasts and publication in general. Then the most recent controversies, concerning the interest rate assumption and forecast, are examined.

\section{Assessment of standard transparency procedures}

Minutes publication. Minutes are central to accountability by giving the rationale for the decision and improving the decision-making process understanding, half-opening the black box of the secret MPC. The position of dissents, published by the BoE and the Copom, is of particular interest to observe and predict future decisions ${ }^{24}$. This publication is supported by the individualistic MPC's promoters, but rejected by the truly collegial type promoters' (especially the ECB) and the literature. It could impair the quality of collegiality and deliberation, and of the decision-making process in general ${ }^{25}$. Yet, the trend is towards publication, in line with the BoE model or the Copom (column 9).

Nominative minutes publication is more controversial (column 10) because it could deteriorate the deliberation quality, MPC members having more prepared statements and being less opened to an unfettered debate. The BoE refuses nominatives minutes, claiming to be already transparent enough for experts to infer who is talking. Still, transparency is not respected, explaining why the Riksbank adopted nominative minutes in 2007. It didn't generate the expected deterioration, improving on the contrary the decision process by requiring an enhanced individual preparation of the meeting and reducing free-riding. It also helps to know each member's position, making them more predictable with time ${ }^{26}$. However, there is not enough data and experience to make a definite assessment, and the Copom could wait before embracing this practice.

Votes' publication is also informative, signalling the degree of confidence in the decision (confidence decreases with the dissents number) and is also a tool for individual accountability when names are published. The Copom could align on the BoE's model by publishing it (column 12) ${ }^{27}$.

The minutes time lag of publication depends on their content. Nominative votes or nominative minutes require a longer time because each member needs to confirm his position ( 2 weeks at the Riksbank). Copom's short lag of publication ( 8 days) reflects non nominative minutes with no votes' publication.

\footnotetext{
${ }^{24}$ Gerlach-Kristen (2004).

${ }^{25}$ See Issing (1999), Meade and Stasavage (2008).

${ }^{26}$ Svensson $(2009$, p. 17).

${ }^{27}$ Strachman (2009, p. 18) is also pro publication, while Costa Filho and Rocha (2009, p. 421) give the pros and cons but don't conclude.
} 
Price index. Headline inflation is more credible and transparent for agents than core inflation ${ }^{28}$. But the latter is often recommended since it gives more flexibility to manage $\varepsilon$ by excluding the more volatile component of $\varpi$ which is supposed to be caused by temporary shock ${ }^{29}$. Hence, it corresponds to the $\varpi$ part that the central bank can control more easily, while ignoring the first round effect of the shock on inflation that should be accommodated. Consequently, it reduces the instrument instability problem, limiting undue volatility of the whole economy. It is also preferable because it excludes the part of inflation that the central bank is not supposed to easily control. Yet disagreements about its definition and measurement techniques are substantial, calling for a variety of measures ${ }^{30}$ and related communication difficulties ${ }^{31}$. Its empirical performances in Brazil are also contrasted in terms of forecasting: it is not a good inflation predictor at the $\bar{\pi}$ time horizon. Moreover, it suffers from bias of economically relevant sizes ${ }^{32}$. These limits explain why core inflation sometimes has been abandoned by inflation target$\mathrm{ers}^{33}$, and why most of them, like the Copom, remain with headline inflation. However, in Brazil's case publishing also core inflation forecasts is informative as the part of inflation the Copom cannot perfectly control (column 14).

Output forecasts. Output $y$ is a MPC's goal (eq. 1), a key transmission channel (eq. 3), a leading indicator of inflation and more generally crucial in case of $\varepsilon$ generating an output-inflation trade-off. Publication of $y$ forecasts by the Copom (column 15) moderates Mishkin's 'dirty little secret of output'. The same reasons call for output gap forecasts $(x)$ publication, and even more because inflation targeting 'science' equations are often expressed in terms of $x$. The Norges Bank is the model in this area, combining $\varpi$ and $x$ forecasts in the same graph as an illustration of the trade-off. The Copom could learn from this experience and publish $x$ forecasts.

Core model publication promotes transparency on the forecasting process, as most central banks do (column 17). Core models result from cooperation among central banks and evolve to incorporate recent innovations, such as the Bank of Canada's new TOTEM (Term of Trade Model) built in 2006. Models can also be evaluated by outside observers (the Pagan report for the BoE). The BACEN ${ }^{34}$ published a small size New Keynesian macroeconomic model that resembles the 4

\footnotetext{
${ }^{28}$ Minella et al. (2002, p. 36).

${ }^{29}$ Bresser-Peirrera (2002, p. 168), Giambiagi and Carvalho (2002, p. 44), Oreiro and Passos (2005, p. 165), Mendonça (2007, p. 448), Vernengo (2008, p. 103), Strachman (2009, p. 18), Montes (2010, p. 106). Most of these studies pro core inflation don't lead a deep empirical investigation.

${ }^{30}$ The BACEN publishes 3 measures of core inflation.

${ }^{31}$ BACEN (2009, p. 130).

${ }^{32}$ Silva Filho and Figueiredo (2009).

${ }^{33}$ Feirrera and Petrassi (2002, p. 10). Rocha and Oreiro (2008, p. 276) find a negative impact of core inflation on income per capita.

${ }^{34}$ See Lima et al. (2009) for a presentation of the BACEN's forecasting and modelling process.
} 
equations model ${ }^{35}$. However, it is not completely described, without calibrations or estimated coefficients, and evolutions since then are not clearly indicated. It contrasts with the medium size model of the transmission mechanism largely described $^{36}$. Nevertheless, the core model used for policy analysis is not published. The staff presented in 2008 a draft of SAMBA (Stochastic Analytical Model with a Bayesian Approach), a DSGE-type model elaborated with the Bank of Canada's support, with calibration and estimations ${ }^{37}$. Like many central banks, the BACEN could publish it as a working paper.

Title of publication containing the forecasts. Credibility had to be earned at the inflation targeting beginning, with strict inflation targeting to demonstrate the commitment to $\bar{\pi}$. Because the focus was mainly on inflation, it was relevant to have an Inflation Report. With time, credibility augments and inflation targeting becomes more flexible ( $\lambda$ increases). The MPC then publishes $i, y$ and $x$ forecasts and the 'Inflation Report' becomes outdated. To reflect this evolution many central banks changed for a 'Monetary Policy Report's8. The Copom could make this move towards more transparency (column 18).

The forecasting rounds number corresponds, in the BoE model, to the quarterly Inflation Report where it is included. But in other central banks it has often been reduced ${ }^{39}$ and can go as low as twice a year in South Africa. This decrease is justified by the forecasting process cost and time, and aims at increasing forecasts quality. It was also related to the more stabilised economy requiring less rounds for forecasts to get any interest. In the long-run the Copom could also reduce to three forecasting rounds a year, but the current financial crisis and the need to dampen agents' uncertainty through information make it inappropriate.

The recently two more debated questions on transparency are now inspected: the interest rate assumption underlying the inflation forecast, and the implied interest rate forecasts publication.

\section{Transparency controversy 1: The interest rate assumption}

After inflation forecasts publication, the next step towards more transparency is the publication of the interest rate assumptions underlying these forecasts. Central Banks use three alternative assumptions: a constant interest rate (CIR), interest rates forecasts extracted from the market (Market Interest Rate or MIR) and their own (Central Bank Endogenous or CBE). Each type of assumption having costs and benefits, there is currently no consensus but diversity of practices, sometimes combining various assumptions (column 20).

\footnotetext{
${ }^{35}$ Bogdanski et al. (2000).

${ }^{36}$ Muinhos and Alves (2003), Minella and Souza-Sobrinho (2009).

${ }^{37}$ Gouvea et al. (2008). DSGE: Dynamic Stochastic General Equilibrium.

${ }^{38}$ Riksbank and Norges Bank in 2007.

${ }^{39}$ From 6 to 3 in 2007 in Norway, 4 to 3 in 2006 in Sweden and in Poland in 2008.
} 


\subsection{Pros and cons CIR}

The CIR assumes that interest rates $i$ will remain constant during the forecast horizon. This legacy of a dependant central bank not deciding $i$ could be replaced now that the MPC has instrument independence. Yet, it stays because of it is simple, easy to explain to the public, with no necessity to publish the instrument path (IP) or to make any pre-commitment - so allowing flexibility in the conduct of $i$. Taken as hypothetical, it could also reveal the forward-looking strategy: the MPC decides $i$ today in order to reach $\bar{\pi}$ two years later ${ }^{40}$. This forecast inflation targeting basic representation is used at the BoE as a robustness check of the MIR projection. But it is considered of second order, and discussed after the MIR in the Inflation Report. Instead, the BACEN treats CIR ('reference scenario') and MIR ('market scenario') on equal basis, and its Inflation Report starts with the CIR and next compare them.

But the CIR is unrealistic: $i$ cannot remain stable if the economy is changing in the next 2 years and the MPC is likely not to respect it. It also suffers from theoretical shortcomings in NK rational expectations forward-looking models where it generates equilibrium indeterminacy (multiple equilibria) and instability of equilibrium under adaptive learning ${ }^{41}$. The CIR actually does not respect the Taylor principle, generating explosive inflation dynamics ${ }^{42}$. Agents under rational expectations understand the unrealistic character of this hypothesis and will not employ this forecast becoming inefficient ${ }^{43}$. More generally, it is inconsistent with optimal model-based projections. Finally, the CIR does not really improve MPC accountability nor policy efficiency.

\subsection{Pros and cons MIR}

Limits to the CIR hypothesis require a time-varying $i$, i.e. $i$ forecasts. The MIR is a possibility adopted by the BoE (since August 2004), that technically is approximated by the forward rates implicit in the yield curve prevailing at the projection time. It is considered as a more helpful benchmark, more efficient than CIR, and reducing MPC-market misunderstandings. Nonetheless, not being MPC's own forecasts, accountability is not enhanced since it even suggests that markets set $i$ for an MPC following them and implicitly having their loss function. The MPC's loss function should on the contrary be aligned on society's, hereby creating a democratic deficit. The MPC's mandate is to lead and regulate markets, not to follow them. Doing this, the MPC loses its independence vis-à-vis markets and fails in its function of providing an anchor to market expectations. The MIR suffers from the same indeterminacy problem than the CIR since the IP remains exogenous to the model. Besides, in theory the MIR is informative if market participants are under rational expectations, but it is usually admitted that they are inefficient as confirmed by the current financial crisis. Moreover, the MPC has more private information on the

\footnotetext{
${ }^{40}$ Colombia's experience with CIR shows it is more complex: the future $i$ at a 2 years horizon is supposed to be changed if inflation forecasts show that inflation is not on target after 2 years.

${ }^{41}$ Honkapohja and Mitra (2005, p. 1869).

${ }^{42}$ Woodford (2007, p. 14).

${ }^{43}$ Leitemo (2003, p. 622).
} 
policy rate it decides than markets have. For all these reasons the MPC and markets are likely to disagree on the IP, urging in fine the MPC to publish its own forecast.

Technical problems also are numerous, the MIR demanding hypotheses on the risk premia when there is little agreement in the literature on how to generate them. Finally, there is a timing problem because markets are evolving while the MIR photograph them at a given point in time; yield curves change continuously and it is sometimes unclear which one the MPC is using.

\subsection{Pros and cons CBE}

The MPC can alternatively publish its own endogenous forecasts $(\mathrm{CBE})^{44}$. Practised since 1997 in New-Zealand, it has become the leading assumption and is generally accompanied by interest rate forecasts publication (column 21). It is alleged to be more realistic than the CIR, more consistent than the MIR, not suffering from indeterminacy and more optimal so better for social welfare. Contrary to previous assumptions, it produces policy rate forecasts that rely directly on the theory, as demonstrated by the model in this domain, the Norges Bank. The optimal IP under flexible inflation targeting is a set of optimal projections $\left(i_{t}^{*}, \ldots, i_{t+h}^{*}\right)$ derived the loss function (eq. 1) minimisation under the NKPC (eq. 2) constraint, and under commitment. Due to its optimal character, this procedure excludes the ad hoc Taylor rule, preferring a targeting rule. It is a sequence of first order conditions satisfying the targeting rule criteria. It results from a dynamic optimisation procedure, derived from the linear-quadratic framework with certainty equivalence and mean forecast targeting (Svensson, 2006, p. 176). The published IP is less formal since chosen so that the resulting $\bar{\pi}$ and $x$ forecasts 'look good': a compromise between the two goals and at an appropriate pace (optimal horizon $h$ ) to manage the Taylor curve ${ }^{45}$.

It yields a central scenario surrounded by a level of uncertainty expressed by the 'fan chart': a density forecast or an uncertainty interval with a probability distribution (bands). The procedure evolves from a 'point forecast targeting' to a 'distribution forecast targeting'. The fan chart also traduces the balance of risks, i.e. the (non)symmetrical shape of the distribution ${ }^{46}$. Higher level of uncertainty (model uncertainty) is taken into account by presenting alternative scenarios and so alternative IP.

Limits. The use of a loss function raises a democratic accountability problem: if the MPC does not decide its mandate, it cannot decide the loss function. If ever it does, is there any guarantee it equals the social loss function? Moreover, where does it come from? A MPC's vote, the staff or from the theory? To our knowledge MPCs do not vote on a loss function $(\lambda)$. The problem becomes more complex when the MPC has to explain changes in loss function weights. In theory, the first

\footnotetext{
${ }^{44}$ Bernanke and Woodford (1997).

${ }^{45}$ See Holmsen et al. (2008).

46 The BACEN's probability distribution often looks symmetric. To avoid this visual impression, it could publish the projected probabilities, as the BoE does. Note that if the distribution is asymmetric it is not 'mean' but 'mode' targeting: a serious problem because in that case there is no reason to preserve a quadratic loss function.
} 
best loss function is welfare-based but it is ad hoc in most central banks ${ }^{47}$, meaning that forecasts are not perfectly optimal ${ }^{48}$. Central banks refuse welfare-based loss function they cannot compute and is not exactly what they do. The targeting rule and the derived optimal reaction function assumed in the optimal IP suffer from the same drawbacks because no MPC gives its policy rule: central banks' DSGE core models incorporate an ad hoc Taylor rule usually estimated ${ }^{49}$; another reason why the IP is not perfectly optimal.

On top of that, the CBE is not an unconditional but model-dependent forecast, implying poor recommendations in a period of structural change. The optimal IP is in addition generally derived from a linear-quadratic framework under certainty equivalence, inducing a lack of robustness to non linearity or asymmetric-non quadratic loss functions that are common in an economic environment often non linear, for instance during the recent financial crisis.

The certainty equivalence principle applied is another problem. There are three levels of uncertainty in increasing order of importance: additive (shocks), multiplicative (parameters) and model uncertainty. Most optimal IP based on certainty equivalence are robust only to the first level, thus irrelevant for model uncertainty central banks face in practice. That is why generated an optimal IP is sometimes difficult in practice. The fan chart and the alternative scenario only slightly reduce this failure. In reality, diversity of judgment is the robustness strategy employed by the MPC against model uncertainty. But this informal addition of judgment moves away from the optimal IP and enhance the difficulty to produce it because of the complexity of mapping judgment into the core model (Archer, 2004, p. 151). The focus on the core model leads to a lack of transparency with a false precision since it does not include many decision elements, like judgment. The Reserve Bank of New Zealand alleviated this problem by publishing less technical projections and more text discussing uncertainty and explaining the decision: in 2002 in the Monetary Policy Statement forecasts moved from the forefront to the back to put verbal explanation first ${ }^{50}$. A complementary robustness approach consists in using McCallum's (1988) approach of a suite of models (DSGE, Bayesian VAR) to produce different interest rate forecasts. For example, the Norges Bank cross-checks the optimal IP with IP from a collection of simple rules ${ }^{51}$.

The optimal IP suffers from other limitations. First, in practice it is voted at each meeting so looks like sequential optimal control theory with potential intertemporal-

\footnotetext{
${ }^{47}$ Norges Bank included.

${ }^{48}$ See Holmsen (2008, p. 17). Ad hoc loss function could be a good approximation of the welfarebased loss function but under specific assumptions.

${ }^{49}$ This is the case in Sweden and New Zealand. Simple rules are considered by some academics as a good approximation of the optimal rule with close welfare performance and more robustness to model uncertainty.

${ }^{50}$ Hampton et al. (2003).

${ }^{51}$ The Copom also utilizes this robustness strategy with VAR models, CIR and MIR to generate forecasts, but for inflation.
} 
inconsistency (Woodford, 2007, p. 17). Secondly, the fan chart is often calculated with margins of error based on past error forecasts that are largely irrelevant in case of structural change ${ }^{52}$. Third, optimising under commitment is not logical since there is no forecast commitment ${ }^{53}$. Finally, the optimal IP requires exchange rate forecasts (published in Norway and Iceland) that are crucial in Brazil where imported inflation is frequent. But they are not reliable because of the high exchange rate volatility in this emerging market economy. To conclude, conditions for a truly optimal IP are often not fulfilled, explaining why many MPCs oppose the CBE hypothesis. The Central Bank of Colombia's experience confirms those pitfalls: it published the IP only from December 2003 to June 2004 and then stopped because of high sensibility to exchange rate volatility and an insufficiently accurate and sensitive core mod$\mathrm{el}^{54}$. There is thus no emergency for the Copom to adopt the CBE.

Despite these limits, the CBE assumption is becoming the common practice of central banks producing their own interest rate forecasts. The latter publication is the next frontier in transparency.

\section{Transparency controversy 2: interest rate forecasts publication}

The IP publication based on the CBE assumption is controversial since many MPCs (Copom, BoE) instead publish the MIR forecast (column 21). The ECB, the Fed or the BoE, do not subscribe to publication because of its low benefits outweighed by considerable costs ${ }^{55}$. On the opposite side, some claim that publication gives large transparency benefits (Svensson, 2006). The publication costs-benefits analysis concerns two areas. First the MPC external dimension: increased transparency could improve policy communication, accountability and effectiveness towards the different publics, financial markets in particular. The second dimension is internal to the MPC, connected to the decision-making efficiency.

\subsection{External: the communication policy as expectations management par ex- cellence}

The IP publication is embedded in the central banking global revolution towards transparency (Blinder, 2004). It is supposed to be beneficial for society and the MPC in terms of accountability and policy effectiveness.

Accountability is increased if the MPC publishes its own forecasts for the policy rate under its direct control. As all transparency procedures, it is also an incentive mechanism ensuring the MPC will by itself share society's loss function.

But this publication mainly aims at improving policy effectiveness. First, it satisfies Lucas' allegation, coming from the rational expectations hypothesis, that

\footnotetext{
${ }^{52}$ That is why the Czech National Bank revises its determination of errors margins every year.

${ }^{53}$ A problem admitted by the Norges Bank (Holmsen et al., 2008, p. 19)

${ }^{54}$ Filacek et al. (2007, p. 568).

${ }^{55}$ See King (2007) for the BoE, Trichet (2006) for the ECB, Kohn (2008) for the Fed, and Gerbasch and Hahn (2008) for academics.
} 
only the central bank following systematically a rule given to agents is efficient. It makes the MPC predictable, allowing markets to infer its reaction function and to incorporate its decisions in advance, reducing markets surprises. The underlying doctrine is that you cannot play against markets so avoid to surprise them.

The second related reason is the role of forward-looking expectations in NK models, where macroeconomic variables current values depend on expectations. The latter are the main transmission channel that the MPC intents to exploit. This NK approach differs from Lucas: you cannot play without agents but you can play with and not against. The MPC and stabilisation policy's effectiveness works through a strategic use of expectations, resulting in markets to do the job for the policymaker, guarantying, accelerating and reinforcing the transmission channel. The IP publication is part of the 'expectations management ${ }^{56}$, the new strategic solution for anchoring expectations, i.e. practically aligning MPC and market expectations. This is the 'expectational' version of the new consensus: stabilising expectations is the best contribution central banks can do to maximise social welfare. Publishing the IP in fine lowers the $i$ level and volatility since the same impact can be achieved with less $i$ movements. In turn, it reduces $w$ and $y$ volatilities, so that in theory it moves the Taylor frontier towards the origin. It also suggests that transparency acts as a policy tool saving $i$ and giving room for manoeuvre, and could be useful in periods where $i$ becomes inefficient (zero lower bound).

The interest rates expectations management is crucial because the MPC controls the short-term, not the market driven long-run interest rate which matters for agents decisions. Most policy-makers rely on the expectations hypothesis of the term structure: the long-run depends on future short-term interest rates expectations, implying that the whole instrument path matters. The MPC publishes the IP to shape markets expectations to guaranty the impact of its short-term on the longrun interest rate, thus on the economy. Market participants are opened to this management because the short-term $i$ is under the MPC control, meaning the IP is the best forecast they can have.

Limits. The IP publication could only slightly increase the MPC accountability since these are forecasts, not decisions. It could also not improve predictability: in practice, perfect predictability is impossible due to the economic uncertainty. Furthermore, evidence on predictability or volatility improvements next to the IP publication is mixed ${ }^{57}$. Besides, it could be for markets an incentive to stop searching the IP by itself, generating a private information loss, reducing social welfare. Market participants focus on the MPC forecasts, not because they are more informative or accurate, but because they are cheaper since common knowledge: a focal point with salient properties coordinating agents at low cost (Morris and Shin, 2002).

In practice, central banks contest this publication mainly because they fear markets misinterpret it as a pre-commitment (Svensson, 2009, p. 15). Markets

\footnotetext{
${ }^{56}$ Woodford (2003).

${ }^{57}$ Holmsen et al. (2008, p. 22) find no improvement, while Ferrero and Secchi (2009) find some but qualitative announcers of the IP (USA, ECB) remain more predictable than quantitative announcers (Norway, New Zealand). Being a recent practice, results are not conclusive.
} 
would be surprised in case of non respect of the IP, with a negative impact on MPC's credibility. This could also entail its flexibility by fear of deviating from the path even when necessary. This is a commitment-flexibility dilemma between pretending to be predictable and have a conditional forecast for a flexible strategy. It can be alleviated by publishing not the official rate but the 3 months rate path (New Zealand). Yet, transparency is not achieved since MPC's future decision is not given. The Riksbank instead choose a mantra: 'a forecast, not a promise'.

More generally, the IP publication is valuable if the MPC has more accurate information than the private-sector, if the latter well understands and extracts the signal and if it is incorporated in its decision. These information questions are controversial in the literature. The IP publication precursor, the Reserve Bank of New Zealand, admits its projections, despite being less erroneous than surveys of forecasters, do not outperform a random walk ${ }^{58}$. Concerning the signal, the optimal IP could be too complex, hence difficult to understand for non specialists and could obfuscate communication with the public (Mishkin, 2004). This limit is usually reduced by explaining the IP verbally with simple code words or more understandable criteria. The risk of markets misunderstanding the IP due to signal extraction problems is also important, generating noise in information transmission: markets overreacting to the IP, volatility augments. The IP publication does not align automatically MPC and markets' expectations alignment. Publication of a quantitative IP could be a better option than its qualitative assessment, but in very uncertain situations markets could prefer qualitative stories easier to understand and less costly to extract. Moreover, signal incorporation in markets' decisions refers to the expectations theory of the term structure which failure is a common place of the literature. The IP publication is not perfectly valid because it treats uncertainty as exogenous when it could be endogenous to bounded rational markets with herd behaviour. It could be unable to steer markets because of differences in view with the MPC, or because the yield curve is segmented with a long-run segment determined by factors different from the policy rate ${ }^{59}$. Besides, the expectations management extension from $\varpi$ to $i$ raises questions about the strategy: is it still inflation forecast targeting or is it forecast targeting? Does the IP become the new intermediate target? Does it become a goal? Is it the come back to the traditional Keynesian interest rate targeting? It leads to a focus on $i$ and less attention on $\bar{\pi}$, obfuscating the inflation targeting regime.

The IP difficulties are in fine so large that its publication could be poorly informative and could even be detrimental for market information. Moreover, it could bring little value added in terms of information compared to $\varpi$ or $y$ forecasts, and to situation of previous high level of transparency, as in the Brazil's case ${ }^{60}$. These small

\footnotetext{
58 Turner (2006).

${ }^{59}$ As during the Greenspan's 'markets conundrum' in 2005.

${ }^{60}$ Brzoza-Brzezina and Kot (2008). The BACEN ranked $12^{\text {th }}$ in the world for transparency in 2004 (Dincer and Eichengreen, 2009).
} 
gains and potential high costs could explain why some MPC are reluctant to publish the IP. These limits seem real in practice: the Riksbank had some troubles in 2007.

\subsection{Internal decision process: the IP decision and the optimal decision-making process}

The IP publication encourages the MPC to think forward-looking, reducing the time inconsistency short-termism. It also disciplines the decision-making becoming more systematic. More generally, it creates a framework for the MPC deliberation, organising and aggregating information. Optimal IP criteria form the MPC's discussion agenda. In the end, it delivers more optimal decisions, closer to the first-best.

The IP should be integrated in the MPC's decision-making process to be its own forecast, with a decision by a majority vote under the median voter theorem (Svensson, 2006, p. 184). This entails each MPC's member to present his own IP, elaborated with staff support due its complexity. Most central banks insist on this MPC-staff interaction, MPC members giving their judgment and hypothesis and the staff proposing forecasts in an iterative process.

Limits. First, to publish the IP the Reserve Bank of New Zealand has no MPC but a single decision-maker, making the IP decision easier. In large and diverse MPC like the ECB or the Fed, it could be difficult and time-consuming. Long discussions reduce the decision quality by loosing time for analysing other important variables for the decision and by deteriorating the MPC comparative advantages: deliberation and collegiality. Agreeing on one single path for $i$ also impacts negatively on the robustness strategy, the diversity of views, which a priori makes it difficult to agree on the IP. These drawbacks are plausible, conditions of application of the median voter theorem being not necessarily fulfilled in the IP case: preferences are not single-peaked, the president controls the agenda, and the vote can be multidimensional (Giavazzi and Mishkin, 2006, p. 110). Nevertheless, Norway or Sweden do so, but are small MPCs. Besides, the optimal IP is largely staff's creation because of its formal complexity, with the risk of being exogenous to the MPC, like the CIR or MIR hypotheses. The MPC-staff interaction and the IP vote reduce but do not eliminate this problem. The MPC should be very careful and control strictly staff work on the IP like at the Riksbank, but it is hard, costly and time-consuming, requiring staff for every member and full-time MPC members with high knowledge in economics. Yet, this would lower MPC's diversity and increase the group-think risk. For all these reasons many MPCs do not vote the IP, are against doing this and against publishing the IP. They consider that the systematic behaviour, strategy and judgment behind $i$ forecasts are more important.

As a conclusion, the IP publication bearing some costs is not a purely beneficial transparency. The implicit optimal degree of transparency varies among central banks, implying that the IP publication is not necessary the 'one best way' for the Copom. However, it is recommended for emerging market economies that supposedly need to earn credibility by being more transparent than industrial countries. The experience of Colombia illustrates it is not always feasible because these countries face a particularly large uncertainty making forecasting a difficult task. 


\section{COMMUNICATION}

Not credible for Neo-Classicals, the 'communication strategy' is a full part of inflation targeting and fits into the NK expectations management. Because agents accept the MPC's decision not only if they know (common knowledge) but also if they understand it (common understanding), communication offers more explanations than publications. It goes further than transparency because its goal is not only predictability but also a common understanding between the MPC and the agents, a shared representation of the future model of the economy.

Number of scheduled meetings. To avoid surprising markets, enhance their predictability and frame their common understanding, MPCs publish a fixed calendar of scheduled meetings. It creates 'rendez-vous' with markets, the latter concentrating their attention on the decision. A decreasing trend in the number of meetings per year is noted, due to more stabilised economies and inflation targeting increased credibility. This 'smoothing' reduces undue markets volatility and gives central banks more time for other tasks such as financial stability and banking supervision. This also goes along with the reduction of forecasting rounds. In accordance with the BoE model, the Copom had 12 meetings a year and cut to 8 in October 2005 thanks to the economy's lowered vulnerability to shocks ${ }^{61}$. At the beginning, with strict inflation targeting, numerous meetings are needed to ensure the disinflation process and the new regime credibility; but once inflation is stabilised, credibility more established and inflation targeting more efficient and flexible, less meetings are required. Yet, the experience of South Africa warns on a lower bound on meetings number ${ }^{62}$.

Video. To increase the impact of decisions and monetary policy effectiveness in general, central banks began recently to use the media, preferring press conference to press release. In contrast with their previous secrecy culture, the BoE or the Copom now present their decisions or Inflation Report on TV (column 23). But they refuse the meetings broadcasting.

Main communication channel of the MPC is generally the forecasts included in the Inflation Report. But its choice is endogenous to the regime, the MPC design and could evolve with time. There is no one best way in theory and in practice (column 24). Being an individualistic committee, minutes could be a natural communication channel for the Copom, with details about individual positions and votes. It cannot favour a press conference just after the meetings because there is no consensus but a majority vote, and dissents that have to be explained; time is missing to make the various positions synthesis, and minutes are the right tool to convey this complexity. The Copom uses the Inflation Report as its main communication channel because it is the more consistent with inflation forecast targeting. However, Fed recent evolution in 2007 to publish individual forecasts and their dispersion in the minutes, like at the Bank of Japan, makes them more informative than the Inflation Report. The individualistic committee natural trend is to publish

\footnotetext{
${ }^{61}$ The Czech National Bank reduced from 12 to 8 in 2008 with a similar justification.

${ }^{62}$ Its 4 meetings a year, corresponding to the Quarterly Bulletin, were too far apart, so two more have been introduced in 2003 .
} 
individual members' forecasts not the MPC's forecast prepared by the staff with the core model that just serving as a robustness check.

\section{CONCLUSION}

The BACEN institutional design ranks well among inflation targeters. However, there is still room for improvement. Being based on the BoE's model, it has not adopted one of its central procedures: the publication of MPC members' individual votes. Moreover, inflation targeting institutional design theory and practice are still under evolution. The Copom should not adopt every new fashion: it could wait and see if experiences demonstrate this transparency is really feasible and valuable in the specific case of an emerging market economy. The optimal interest rate path publication for example seems less relevant than the publication of nominative minutes decided by the Riksbank in May 2007.

Possible advances in the Copom's institutional design do not concern inflation targeting credibility construction but should enhance its flexibility and the MPC efficiency. Inflation targeting is not necessarily the first best in these areas: the Copom could learn from the Fed experience with a dual mandate and a decisionmaking process based upon MPC members' individual forecasts.

\section{REFERENCES}

ARCHER, D. (2004) "Communication with the public". In Practical Experience with Inflation Targeting, Czech National Bank, pp. 145-63.

ARESTIS, P., DE PAULA, L. and F. FERRARI-FILHO (2009) “A nova política monetária: uma análise do regime de metas de inflação no Brasil". Economia e Sociedade, 18(1):1-30.

BANCO CENTRAL DO BRASIL (2009) Relatorio de Inflação, Dezembro.

BARRO, R. and D. GORDON (1983) "A positive theory of monetary policy in a natural rate model". Journal of Political Economy, 91(4): 589-610.

BATINI, N., K. KUTTNER and D. LAXTON (2005) "Does inflation targeting work in emerging markets?”. IMF, World Economic Outlook, September, pp. 161-186.

BERNANKE, B., WOODFORD, M. (1997) "Inflation Forecasts and Monetary Policy". Journal of Money, Credit, and Banking, 29(4): 653-84.

BLINDER, A. (2004) The Quiet Revolution: Central Banking Goes Modern. New Haven: Yale University Press.

BOGDANKSI, J., Tombini, A. and S. Ribeiro da Costa WERLANG (2000) "Implementing inflation targeting in Brazil”. Banco Central do Brasil, Working Paper No.1.

BRESSER-PERREIRA, L., NAKANO, Y. (2002) "Uma estratégia de desenvolvimento com estabilidade". Revista de Economia Política, 22(3):146-77.

BRZOZA-BRZEZINA, M., KOT, A. (2008) "The relativity theory revisited: Is publishing interest rate forecasts really so valuable?”. MPRA Paper No.10296.

CERISOLA, M., GELOS, G. (2009) "What drives inflation expectations in Brazil? An empirical analysis”. Applied Economics, 41: 1215-27

CLARIDA, R., GALI, J. and M. GERTLER (1999) "The science of monetary policy: A New Keynesian perspective". Journal of Economic Literature, 37(4): 1661-1707.

COSTA FILHO, A. and F. ROCHA (2009) "Communicação e politica monetária no Brasil”. Revista Brasileira de Economia, 63(4): 405-22. 
CROWE, C., MEADE, E. (2007) “The evolution of central bank governance around the world". Journal of Economic Perspectives, 21(4): 69-90.

DINCER, N., EICHENGREEN, B. (2009) "Central bank transparency: causes, consequences and updates". NBER Working Paper No. 14791.

EHRART, S., VASQUEZ-PAZ, J. (2007) "Optimal monetary policy committee size: theory and cross country evidence". Kiel Institute for the World Economy, Working Paper No.439.

FAUST, J., HENDERSON, D. (2004) “Is inflation targeting best-practice monetary policy?”. FRB St Louis Economic Review, 86(4): 117-43.

FEIRRERA, T. and M. PETRASSI (2002) "Regime de metas para a inflação: resenha sobre a experiência internacional”. Banco Central do Brasil, Notas Técnicas No.30.

FEITOSA, M., TABAK, B. (2008) "How informative are interest rate survey-based forecasts?". Brazilian Administration Review, 5(4): 304-18.

FERRERO, G., SECCHI, A. (2009) “The announcement of policy intentions”. Bank of Italy, Working Papers No.720.

FILACEK, J., KOMAREK, L., KRAL, P. (2007) "Why central bankers should disclose interest rate forecast". Czech Journal of Economics and Finance, 57(11-12): 558-76.

FISCHER, S. (1995) "Central-bank independence revisited”. American Economic Review, 85(2):2016.

FREEDMAN, C. and D. LAXTON (2009) "Inflation targeting pillars: transparency and accountability”. IMF Working Paper No. 09/262.

FREEDMAN, C. and I. ÖTKER-ROBE (2010) "Important elements for inflation targeting for emerging economies". IMF Working Paper No. 10/113.

GERBASCH, H., HAHN, V. (2008) "Monetary policy inclinations”. CEPR Discussion Paper No. 6761.

GERLACH-KRISTEN, P. (2004) "Is the MPC's voting record informative about future UK monetary policy?". Scandinavian Journal of Economics, 106(3): 299-313.

GIAMBIAGI, F., CARVALHO, J.(2002) "As metas de de inflação: sugestões para um regime permanente”. Revista de Economia Política, 22(3): 25-45.

GIAMBIAGI, F., A. MATHIAS and E. VELHO (2006) "O aperfeiçoamento do regime de metas de inflação no Brasil”. Economia Aplicada, 10(3): 443-75.

GIAVAZZI, F, MISHKIN, F. (2006) "An evaluation of Swedish monetary policy between 1995 and 2005". Report for the Riksdag Committee on Finance, November.

GOODHART, C. (1995) The Central Bank and the Financial System. Cambridge (MA): MIT Press.

GOODHART, C. (2003) “The constitutional position of the central bank". In Friedman, M. and C. Goodhart, Money, Inflation, and the Constitutional Position of the Central Bank, The Institute of Economic Affairs, pp. 91-109.

GOUVEA, S., MINELlA, A., SANTOS, R., SOUZA-SOBRINHO, (2008) "SAMBA: Stochastic Analytical Model with Bayesian Approach for the Brazilian Economy". Mimeo, September.

GREENSPAN, A. (2004) "Risk and uncertainty in monetary policy". American Economic Review, 94(2): 33-40.

HAMPTON, T., PHILLIP, R. STEPHENS, D. (2003) "Monetary policy communication and uncertainty". Reserve Bank of New Zealand Bulletin, 66(2): 29-34.

HEENAN, G., PETER, M. and S. ROGER (2006) "Implementing inflation targeting: institutional arrangements, target design, and communications". IMF Working Paper, No.06/278.

HOLMSEN, A, QVIGSTAD, J., ROISLAND, O., Solberg-Johansen, K. (2008) “Communicating monetary policy intentions: the case of the Norges Bank". Norges Bank, Working Paper No.200820.

HONKAPOHJA, S., MITRA, K. (2005) "Performance of inflation targeting based on constant interest rate projections". Journal of Economic Dynamics and Control, 29(11): 1867-92.

HUTCHISON, M. and C. WALSH (1998) "The output-inflation tradeoff and central bank reform: evidence from New Zealand”. Economic Journal, 108: 703-25.

ISSING O. (1999) "The Eurosystem: transparent and accountable or Willem in Euroland". Journal of Common Market Studies, 37(3): 503-19.

KANCZUK, F. (2004) “Choques de oferta em modelos de metas inflacionárias”. Revista Brasileira de Economia, 58(4): 559-81. 
KING, M. (2004) “The institutions of monetary policy”. Speech, Bank of England, January 4.

KING, M. (2007) "The MPC ten years on". Speech, Bank of England, May 2.

KOHN, D. (2008) "Recent and prospective developments in monetary policy transparency and communications: A global perspective". Speech, Federal Reserve of the United States, January 5.

LEITEMO, K. (2003) “Targeting inflation by constant-interest rate forecasts”. Journal of Money, Credit, and Banking, 35(4): 609-26.

LIMA, E., ARAUJO, F., DA COSTA E SILVA, R. (2009) "Forecasting and macroeconomic models at the Banco Central do Brasil”. XI Seminario anual de metas para a inflaçao, BACEN.

LOHMANN, S. (1992) "Optimal commitment in monetary policy: credibility versus flexibility". American Economic Review, 82(1): 286-99.

MASSON, P., M. SAVASTANO, S. SHARMA (1997) “The Scope for inflation targeting in developing countries". IMF Working Paper No. 97/130.

MCCALLUM, B. (1988) "Robustness Properties of a Rule for Monetary Policy". Carnegie- Rochester Conference Series on Public Policy, 29: 173-203.

MEADE, E., STASAVAGE, D. (2008) "Publicity of Debate and the Incentive to dissent: Evidence from the US Federal Reserve". The Economic Journal, 118: 685-717.

MEIRELLES, H. (2007) Pronunciamento no Encerramento do IX Seminário Metas para a Inflação do Banco Central do Brasil, August 24.

MEIRELLES, H. (2008) Pronunciamento no X Seminário Annual de Metas para a Inflação do Banco Central do Brasil, August 4.

MENDONÇA, H. (2002) “Metas para a taxa de câmbio, agregados monetários e inflação". Revista de Economia Política, 22(1): 34-52.

MENDONÇA, H. (2007) "Metas para inflação e taxas de juros no Brasil: uma análise do efeito dos preços livres e administrativos”. Revista de Economia Política, 27(3): 431-51.

MENDONÇA, H. and INHUDES, A. (2010) "Transparência do banco central: uma análise para o caso brasileiro". Revista de Economia Política, 30(1): 159-77.

MINELLA, A., P. SPRINGER DE FREITAS, I. GOLDFAJN and M. MUINHOS (2002) "Inflation targeting in Brazil: lessons and challenges". Banco Central do Brasil, Working Paper No.53.

MISHKIN, F. (2004) “Can Central Bank Transparency go Too Far?”. In Kent, C., Guttmann, S. (eds.), The Future of Inflation Targeting, Reserve Bank of Australia, pp. 48-65.

MONTES, G. (2010) "Uncertainties, monetary policy and financial stability: challenges on inflation targeting”. Brazilian Journal of Political Economy, 30(1): 89-111.

MORRIS, S., SHIN, H. (2002) "Social Value of Public Information". American Economic Review, 92(5): 1521-34.

MUINHOS, M., ALVES, S. (2003) "Medium-size macroeconomic model for the Brazilian economy". Banco Central do Brasil, Working Paper No.64.

MUINHOS, M., SOUZA-SOBRINHO, N. (2009) "Monetary channels in Brazil through the lens of a semi-structural model”. Banco Central do Brasil, Working Paper No.181.

NICHOLL, P., ARCHER, D. (1992) “An announced downward path for inflation”. Reserve Bank of New Zealand Bulletin, 55(4): 315-23.

OREIRO, J., PASSOS, M. (2005) “A governança da politica monetária brasileira: análise e proposta de mudança”. Indicadores Econômicos, 33(1): 157-68.

PERSSON, T. and G. TABELLINI (1993) "Designing institutions for monetary stability". Carnegie-Rochester Conference Series on Public Policy, 39: 58-84.

PETURSSON, T. (2004) "Formulation of inflation targeting around the world". Monetary Bulletin, Central Bank of Iceland, 1: 57-84.

REDDELL, M. (1999) "Origins and early development of the inflation target". Reserve Bank of New Zealand Bulletin, 62(3): 63-71.

ROCHA, M., CURADO, M. (2009) “Adoção do regime de metas de inflação e as funções de reação dos bancos centrais”. Análise Econômica, 51:249-72.

ROCHA, M., OREIRO, J. (2008) “A experiência internacional de regime de metas de inflação: uma análise com painel dinâmico”. Nova Economia, 18(2):267-91.

ROGOFF, K. (1985) “The optimal degree of commitment to an intermediate monetary target”. Quarterly Journal of Economics, 100(4):1169-89. 
SERRANO, F. (2010) “Juros, câmbio e o sistema de metas de inflação no brasil”. Revista de Economia Politica, 30(1): 63-72.

SHERWIN, M. (1999) "Strategic choices in inflation targeting: the New Zealand experience". Reserve Bank of New Zealand Bulletin, 62(2): 73-88.

SHERWIN, M. (2000) "Institutional frameworks for inflation targeting”. Reserve Bank of New Zealand Bulletin, 63(4): 28-34.

SIKLOS, P. (2002) The Changing Face of Central Banking. Cambridge: Cambridge University Press.

SILVA FILHO, T., FIGUEIREDO, F. (2009) "Has core inflation been doing a good job in Brazil?". MPRA Paper No.23340.

SINGLETON, J., GRIMES, A., G. HAWKE and F. HOLMES (2006) Innovation and Independence. The Reserve Bank of New Zealand 1973-2002. Auckland: Auckland University Press.

STRACHMAN, E. (2009) "Implementing inflation targeting in Brazil: an institutional analysis". MPRA Working Paper No. 15131.

SVENSSON, L. (1997) "Inflation forecast targeting: implementing and monitoring inflation targets". European Economic Review, 41(6): 1111-46.

SVENSSON, L. (2006) "The Instrument-Rate Projection under Inflation Targeting: The Norwegian Example”. In Stability and Economic Growth: The Role of Central Banks, Banco de Mexico, pp.175-98.

SVENSSON, L. (2009) “Transparency under flexible inflation targeting: Experiences and Challenges". Paper presented at the Riksbank's conference 'Refining Monetary Policy: Transparency and Real Stability', September 5-6, 2008.

TAYLOR, J. (1979) "Estimation and control of an econometric model with rational expectations". Econometrica, 47(5): 1267-86.

TRICHET, J.C. (2006) "Monetary policy and economic prospects in the Euro Area”. Speech, European Central Bank, February 6.

TULADHAR, A. (2005) "Governance structures and decision-making roles in inflation targeting central banks”. IMF Working Paper No. 05/183.

TURNER, J. (2006) “An assessment of recent Reserve Bank forecasts”. Reserve Bank of New Zealand Bulletin, 69(3): 38-43.

VERNENGO, M. (2008) “The political economy of monetary institutions in Brazil: The limits of the inflation-targeting strategy, 1999-2005”. Review of Political Economy, 20(1): 95-110.

WALLER, C. (1992) “A bargaining model of partisan appointments to the central bank". Journal of Monetary Economics, 29(3): 411-28.

WALSH, C. (1995) “Optimal contracts for central bankers”. American Economic Review, 85(1): 15067.

WALSH, C. (2000) "Monetary policy design: institutional developments from a contractual perspective". International Finance, 3(3): 375-89.

WOODFORD, M. (2003) Interest and Prices: Foundations of a Theory of Monetary Policy. Princeton: Princeton University Press.

WOODFORD, M. (2007) "The case for forecast targeting as a monetary policy strategy". Journal of Economic Perspectives, 21(4): 3-24. 


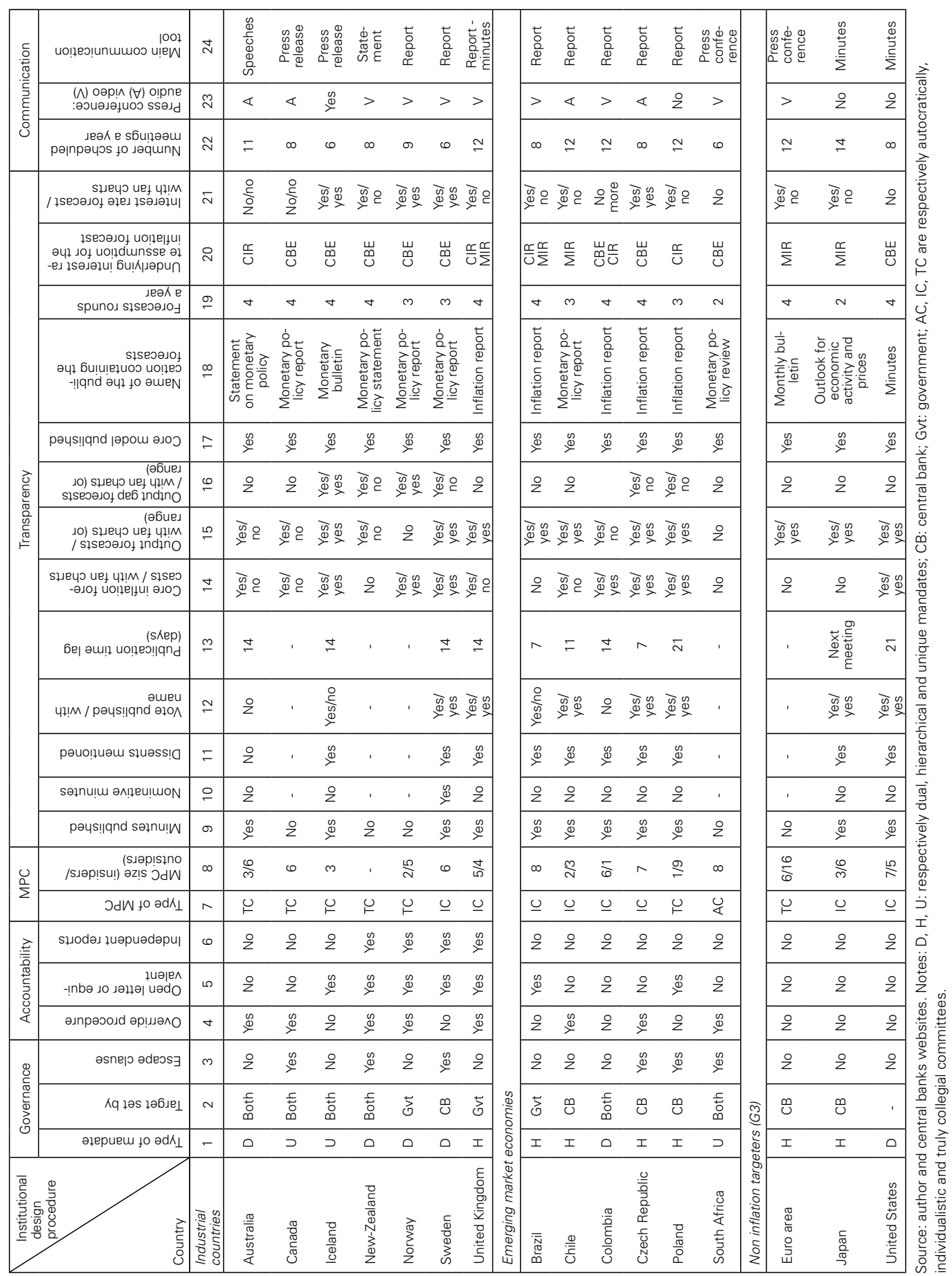

